NBER WORKING PAPER SERIES

\title{
VOLATILITY IN AN ERA OF REDUCED UNCERTAINTY: LESSONS FROM PAX BRITANNICA
}

\author{
William O. Brown \\ Richard C. K. Burdekin \\ Marc D. Weidenmier \\ Working Paper 11319 \\ http://www.nber.org/papers/w11319

\begin{abstract}
NATIONAL BUREAU OF ECONOMIC RESEARCH
1050 Massachusetts Avenue

Cambridge, MA 02138

May 2005
\end{abstract}

This paper is forthcoming in the Journal of Financial Economics. The views expressed herein are those of the author(s) and do not necessarily reflect the views of the National Bureau of Economic Research.

(C2005 by William O. Brown, Richard C K. Burdekin, and Marc D. Weidenmier. All rights reserved. Short sections of text, not to exceed two paragraphs, may be quoted without explicit permission provided that full credit, including (C) notice, is given to the source. 
Volatility in an Era of Reduced Uncertainty: Lessons from Pax Britannica

William O. Brown, Richard C K. Burdekin, and Marc D. Weidenmier

NBER Working Paper No. 11319

May 2005

JEL No. JE6, H3, N2

\begin{abstract}
$\underline{\text { ABSTRACT }}$
Although it has been well established that financial volatility is related to news and macroeconomic shocks, there has been less emphasis on the importance of underlying economic and political stability. In this paper we study the behavior of consol returns since 1729 and identify a greater-than$50 \%$ decline in volatility from the end of the Napoleonic wars in 1815 until the First World War. News events and macroeconomic variables cannot account for this extended period of reduced volatility. Underlying political stability under Pax Britannica seems to be a more likely explanation, however.

William O. Brown

Claremont McKenna College

500 E. Ninth Street

Claremont, CA 91711

wbrown@mckenna.edu

Richard C. K. Burdekin

Claremont McKenna College

500 E. Ninth Street

Claremont, CA 91711

burdekin@mckenna.edu

Marc D. Weidenmier

Claremont McKenna College

500 E. Ninth Street

Claremont, CA 91711

and NBER

mweidenmier@mckenna.edu
\end{abstract}




\section{Volatility in an Era of Reduced Uncertainty: Lessons from Pax Britannica}

\section{Introduction}

There is considerable evidence indicating that financial market volatility is related to news. Significant economic and political events can have dramatic impacts on markets. Patterns in financial market activity often mimic various measures of public news (Niederhoffer, 1971; Penman, 1987; Berry and Howe, 1993; Jones, Lamont and Lumsdaine, 1999) and are directly related to macroeconomic policy moves and other government announcements (Ederington and Lee, 1993; Fleming and Remolona, 1999; Fair, 2002; 2003). While relationships between different measures of news and volatility are well established, there is little evidence that news can explain more than a small fraction of the movement in financial markets ex-post. The overall proportion of the movement in security prices that can be explained by news is low regardless of whether the analysis is focused on individual securities (Roll, 1988), the overall equity market (Cutler, Poterba and Summers, 1989; Talmor, Haugen and Torous, 1991; Mitchell and Mulherin, 1994), futures markets (Fair, 2002; 2003) or bond markets (Jones, Lamont and Lumsdaine, 1999). Individual macroeconomic series like inflation and unemployment, meanwhile, have generally been found to have limited explanatory power in such studies (cf, Schwert, 1989a). As a result, our understanding of what causes financial market volatility is still quite limited.

In this paper we explore the idea that volatility at any point in time is not only related to single isolated events but also is dependent upon the overall economic and political climate. Increased stock market volatility during the Great Depression, for example, may reflect not only increased short-run uncertainty but also more fundamental concerns about whether the capitalist 
system itself would survive (Schwert, 1989a; Voth, 2002). ${ }^{1}$ Stability in financial markets is scarcely possible if the economic and political regime is under threat. In this paper we use longrun data on British consols to examine how changes in financial market volatility since 1729 may be linked to stability over the course of Britain's imperial era. We find a striking decline in volatility over the 1816-1913 period at the height of Britain's imperial power, an era of British preeminence known as Pax Britannica. Greater uncertainty associated with the various conflicts with France prior to Napoleon's final defeat at Waterloo in 1815 is reflected not only in large event-driven moves in consol prices but also significantly higher average volatility than the post1815 period. After remaining low during the period of Pax Britannica, volatility then rises again following renewed global conflict with the outbreak of the First World War in 1914.

Consols themselves are a well-known textbook case where the bond price is exactly inversely related to interest rates. This special property follows from their not having a fixed redemption date but rather promising a fixed coupon payment indefinitely - or, at least, so long as the British government stood behind its obligation to bondholders. By the end of the eighteenth century consols were an established bellwether security and remained an important debt instrument into the early part of the twentieth century (see, for example, Giffen, 1899; Hargreaves, 1930). Moreover, before Britain's exit from the gold standard in 1931, nominal debt obligations were effectively fixed in real terms. Under these circumstances, Barro (1999) argues that consols, as indexed perpetuities with constant real payouts, are the optimal form of

\footnotetext{
${ }^{1}$ By contrast, even the worst nineteenth century US financial panics appear to have produced no lasting volatility effects (Schwert, 1989b). It remains to be seen whether the increased volatility at the end of the 1990s will prove to be just another such blip or something more ominous (Schwert, 2002).
} 
debt finance. Barro (1987, p. 225) also points to the absence of "most other governmental interventions, such as extensive price and interest-rate controls, which often accompany wars." ${ }^{2}$ Amidst the extensive and continuing literature on the impact of the British Empire, its potential role in bringing stability to financial markets has received surprisingly little attention. Although it is hard, if not impossible, to fully quantify the effects of the dramatic reduction in the volatility of consol returns after 1815, we show that consol returns are on average higher during the 1816-1913 period compared to the British experience before and after this interval. Moreover, the high level of interest rate stability clearly distinguished British financial markets from those of the other powers. The growth of bankers' deposits in London to a level more than double the combined totals in Paris, New York and the German Empire in the early 1870s (Bagehot, 1873) itself occurred in the midst of the period of greatly enhanced stability in consol returns that prevailed until the outbreak of the First World War. ${ }^{3}$

\section{Data}

Our series on British 3\% consols is drawn from the international database provided by Global Financial Data, Inc. (http://www.globalfindata.com). Pre-1751 data are based on the perpetual $3 \%$ annuities that were first issued in 1726 - with the various series all being combined into $3 \%$ consols under the 1751 Consolidating Act (Neal, 1990, p. 117). The 1751 debt was redeemed and replaced by new "Goschen" consols that yielded 2.75\% from 1889-1903 and 2.5\% after 1903. Under the terms of this conversion, first proposed by Chancellor of the Exchequer G. J.

\footnotetext{
${ }^{2}$ In addition to Barro's (1987) analysis of the movement of consols yields over the 1730-1913 period, shorter subperiods have been examined by Brown and Easton (1989), Elmendorf, Hirschfeld and Weil (1996), Mitchell, Brown and Easton (2002) and Ferguson (2003).

${ }^{3}$ The long period of relative quiescence in consol prices after Waterloo also coincides with a period of increased
} 
Goschen in his March 9, 1888 speech, the new consols could be called in at par after April 1923 (for details, see Miller, 1890; Harley, 1976; Klovland, 1994). The old consols had generally only been redeemable upon receipt of a year's notice and in lots of not less than $£ 500,000$ (Miller, 1890, p. 438). Although consols generally traded below par for most of our sample period, we allow for the potential effect that expectations of forced redemption may have had on volatility. ${ }^{4}$

We begin with an overview of the evolution of consol prices over the post-1729 period as depicted in Figure 1. By ending the sample period in 1959 we exclude the inflationary period that sets in during the 1960s. This means that nominal returns remain roughly equivalent to real returns over our estimation period and -- in sharp contrast to later developments -- it is unlikely that inflation expectations exerted more than a negligible influence on investor behavior. Although a case could also be made for ending the estimation period even earlier, either at the time of the First World War (Barro, 1987) or with Britain's final exit from the gold standard in 1931, the results of formal structural break tests suggest no major shift in the series occurs until the late $1950 \mathrm{~s}^{5}$

Consol prices trade in a relatively narrow range over the 230 year period. Following brief spells below $80 \%$ of par during such episodes as the Jacobite Rebellion (1745-1746), the latter part of "King George's War" with France (March 1748), and the Seven Years' War (17541763), the consols return to these depressed levels at the beginning of the American Revolution

\footnotetext{
financial market integration (Sylla, Wilson and Wright, 2004).

${ }^{4}$ While the prices of consols are also subject to the usual ex-dividend effects on the days when the quarterly (or, until 1884, semi-annual) interest payments were made, we have not corrected for this as it could not be expected to significantly change the long-run evolution of consol prices over the 230 year sample period that we examine.

${ }^{5}$ Testing for structural breaks in consol prices over the full available sample of 1729-2002 using the Bai and Perron (1998) and Banerjee, Lumsdaine and Stock (1992) procedures always identifies a single break in the period around 1960. (Testing for breaks in consol returns yields no significant break points.)
} 
and experience a continual decline until 1785. From 1786, when a major debt reduction act was passed, ${ }^{6}$ until 1792 we see an uptrend that brings consol prices nearly back to par. The war with post-revolutionary France (1793-1802) begins another period of increased volatility and price declines, however, that despite intermittent reverses did not come to an end until the final defeat of Napoleon at Waterloo in 1815.

The majority of the large shifts in the consol series fall between the Seven Years' War and Waterloo. Over that period, Britain and France were essentially competing for world supremacy and consol prices appear highly sensitive to military events and news signaling the outbreak or cessation of hostilities. After Waterloo, the consols begin a period of slow increase and seem to be much less sensitive to military events. The sustained uptrend in consol prices is briefly interrupted by a sharp decline during the $1819-1820$ period, which coincided with a return to the gold standard, and then another decline beginning in early 1825 and lasting until mid 1826 that coincided with a banking crisis (Kynaston, 1995; Neal, 1998). From April 1831 until September 1910 the bonds never traded below $80 \%$ of par value and frequently traded at above $100 \%$ of par value, peaking at $113.75 \%$ of par in May 1897 .

The extended period of strength and stability in consol prices includes, at its center, the 1837-1901 reign of the Queen Victoria at the zenith of the British Empire. This was a period of remarkable political stability within Britain and worldwide. The most significant drop during the period occurs over the 1846 to 1850 interval, coinciding with both the 1848 revolution in France and the Irish potato famine -- and closely following the budgetary problems of the 1840 s that

\footnotetext{
${ }^{6}$ The National Debt Reduction Act that was passed in 1786 established Prime Minster William Pitt's sinking fund for the consols. These measures followed a proposal by Dr. Richard Price that was referred to in the King's Speech of 1782 and which was the subject of correspondence between Pitt and Price after Pitt became Prime Minister in 1784 (see Hargreaves, 1930, Chapter VI).
} 
saw the reintroduction of the income tax in 1842 under Prime Minister Robert Peel. ${ }^{7}$ Neither the Crimean War (1854-1856) nor the American Civil War (1861-1865) appears to have had effects on consol prices remotely comparable to major pre-1816 military events. Although Ferguson (2003) argues that European debt series generally remain highly sensitive to war and political shocks until 1880 , our analysis suggests that these effects had already become less important for British consols by the 1820 s. Even large losses like the 10,000 men annihilated by the Mahdi's forces in Sudan in 1883, while causing great consternation in England at the time (see, for example, Farwell, 1972, p. 272), appear to have made no dent in consol prices. From the 1897 peak, consol prices begin a slow but steady decline, however, with prices bottoming at less than $50 \%$ of par in the early $1920 \mathrm{~s}^{8}$

The ten largest upward and ten largest downward monthly price shifts are set out in Table 1. Nine of the ten largest monthly price increases occur between 1748 and 1814 and appear to be associated either with favorable developments in the various wars with France or with major financial policy changes. There are three shifts in 1761-1762 in the face of British captures of French territory near the end of the Seven Years' War $^{9}$ and there are four further shifts in 17981801 during the further conflict with France following the French Revolution. Additional large gains occur in 1748 with the conclusion of "King George's War" against France. The 1797 gains coincide with the easing of credit conditions after the suspension of gold convertibility in February 1797, while the June 1799 increase occurs in the midst of the first collections from

\footnotetext{
${ }^{7}$ The income tax had previously been abolished in 1816 after the conclusion of the Napoleonic wars.

${ }^{8}$ After a temporary recovery following Britain's exit from the Gold Standard in 1931, consol prices renew their decline until the outbreak of the Second World War in September 1939. While the existence of capital controls in and around the war period make it difficult to interpret the changes, some of the gains seen over the 1939-1947 period may reflect a renewed "flight to quality" of funds exiting Continental Europe.

${ }^{9}$ The February 1762 successes in the Caribbean were themselves closely followed by the initiation of settlement talks by French emissaries in the early spring of 1762 (Koehn, 1994, p. 15).
} 
Britain's new income tax as well as Britain's entry into the Second Coalition against France. ${ }^{10}$ The imminent first defeat of Napoleon in early 1814 appears to lie behind another large price increase in January 1814. The single top-ten price increase in the twentieth century occurs in July 1932. This shift occurs in the month following hefty interest rate cuts in June 1932 that formed part of the War Loan conversion. As was true in 1797, the easing seems to have triggered a bond market rally.

As with the increases, a majority of the ten largest monthly price declines are concentrated in the late eighteenth and early nineteenth centuries. Seven of the ten largest shifts occur between 1778 and 1815. The March 1778 shift appears to be associated with French entry on the American side in the fight against British rule and further shifts occur in 1792 and 1799 following the outbreak of France's own revolutionary war. There is another negative shift in 1803 in the year when renewed fighting erupted against Napoleon and a March 1815 shift occurs at the time that Napoleon reclaimed Paris after escaping from exile on Elba. There are three topten decreases in the twentieth century. The first of these, in January 1915, occurs in the first month that trading resumed following the outbreak of the First World War. The second shift in September 1931 appears to be triggered by Britain's exit from the international gold standard. The final shift in February 1937 occurs at the time of a new UK Government proposal for a $£ 400$ million loan to fund re-armament expenditures (coincident with a Nationalist offensive in the Spanish Civil War). ${ }^{11}$ The existence of a 1937 shift but no large shift with the outbreak of the

\footnotetext{
${ }^{10}$ The first payments on the new tax were due in June 1799 and Neal (2000, p. 138) emphasizes that, with interest payments on the $3 \%$ consols now guaranteed against income tax revenues, the government was able "to tap into the profits of European merchants now directing all their affairs from London .. [allowing] huge sums to be raised on the capital markets."

${ }^{11}$ The Financial Chronicle (February 13, 1937, p. 991) refers to the capture of Malaga as an event that "broke the long deadlock in the Spanish rebellion" and also discusses the role played by Italian "volunteers" in the assault on the city. Re-armament concerns were also rising at the same time, however (see the Financial Chronicle, February
} 
Second World War in 1939 may reflect the interest rate controls -- as well as capital controls -that were imposed during the war with Germany. ${ }^{12}$

The fact that the majority of the largest movements occur before 1816 is consistent with the enhanced stability of consols during most of the nineteenth century. Figure 2 shows the monthly percentage changes in the consol series. Volatility clearly seems to decline during the first quarter of the nineteenth century and is much lower during the second half of century than in the rest of the sample. There is also a sharp decline in volatility during the period surrounding the Second World War, which is consistent with the existence of wartime control measures. ${ }^{13}$

\section{Volatility vs. Stability in Consol Prices}

The post-Waterloo period of stability is clearly evident in Figure 3, which lays out the conditional standard deviation of consol returns over the $1730-1959$ period. These conditional standard deviations are derived from estimation of the time series properties of the variance of consol returns as laid out in Table 2 (column 1) below. The data are modeled as a generalized autoregressive conditional heteroskedastic $(\mathrm{GARCH})$ process with one autoregressive $(\mathrm{AR})$ term in the mean equation and the lagged squared residuals and the lagged conditional variance included alongside a "premium" term that allows for potential callability effects - with the PREMIUM variable defined as the percentage difference between the log of the bond price and

20, 1937; and The Economist, February 13, 1937 and February 20, 1937), and the sharp downturn in consol prices more likely reflects budgetary concerns rather than the events in Spain.

${ }^{12}$ Exports from Britain not deemed necessary to the war effort were disallowed and countries exporting to Britain largely accrued funds that were placed in special accounts and could not readily be remitted outside their own territory (see Harrod, 1958, Chapter 5). Domestically, rent controls were imposed upon the outbreak of war and general price controls followed at the beginning of 1940. Brown (1955, p. 211) points out that all this left little room for interest rates to be affected by expectations of inflation: "Income receivers accumulated funds because their opportunities for spending on consumer goods and services were curtailed, mainly by rationing and price control." ${ }^{13}$ By terminating our sample in 1959 we do, of course, miss the ensuing prolonged decline in consol prices that sets 
the $\log$ of $100 .{ }^{14}$ We employ a t-distribution (t-GARCH) throughout in order to account for the fat-tailed innovations typical in financial data (Bollerslev, 1987). ${ }^{15}$ The ARCH and GARCH parameters are always significant at the $99 \%$ level in the full-sample results shown in Table 2. We find that the sum of the $\mathrm{ARCH}$ and $\mathrm{GARCH}$ coefficients is close to one indicating a high degree of persistence in the conditional variance of consol returns. The premium also has a negative impact that is significant at the $95 \%$ level or better in all the specifications. This provides some evidence that volatility declines as the probability of redemption increases.

The high volatility period before Waterloo reaches its peak around the turn of the nineteenth century, with some of the greatest volatility seemingly arising around the time of the 1789 French revolution. By contrast, the post-1815 period was marked by considerable domestic political and financial stability with no constitutional crises of the type that emerged in the late eighteenth century. The decline in volatility after Waterloo is really quite dramatic, with the extent of the fluctuations falling to less than half of the earlier levels. Although this decline is briefly punctured by events such as the banking crises of the $1820 \mathrm{~s}$, the 1848 revolution in France (followed in 1854 by the Crimean War), and the outbreak of the Boer War in 1899, the contrast with the earlier period is unequivocal. The First World War subsequently appears to trigger another high volatility period. While the fluctuations do not generally match the magnitudes seen in the early part of the sample, the large "spike" in the standard deviation of the series at the beginning of the 1930s exceeds anything seen during either of the two world wars.

in with the inflationary trend of the 1960s and 1970s that drove interest rates to higher and higher levels.

${ }^{14} \mathrm{We}$ are grateful to an anonymous referee for suggesting this approach to capturing the potential effects of redemption on volatility.

${ }^{15}$ All models presented in Tables 2 and 3 use t-distributions of approximately 5 to 6 degrees of freedom. We experimented with changing the degrees of freedom but it did not change the results. Re-estimation using EGARCH (Nelson, 1991) as a robustness check had no effect on any of the inferences drawn below. 
This is consistent with the volatility spike in the interwar period seen in British stock market data and other major national stock markets (Voth, 2002) including the United States (Schwert, 1989a).

The sharp decline in the volatility of consol returns after the end of the Napoleonic wars in 1815 itself occurs well in advance of the heyday of the classical gold standard, which is usually dated from 1880-1913. The low volatility period does, however, appear to correspond well with the period of Pax Britannica. In order to formally test for the relative importance of Pax Britannica (PAX: 1816-1913) vs. the classical gold standard (GOLD: 1880-1913) we enter dummies for these two periods in our conditional variance specification of consol returns, estimated still using tGARCH as a $(1,1)$ process. ${ }^{16}$ We also control for the effects of inflation (INF), allowing for up to a three-period lag. ${ }^{17}$ This variable allows for the premise that financial stability is directly tied to stability in aggregate prices (Bordo, Wheelock and Decker, 2003). Real effects are controlled for by adding a dummy for whether or not the economy is in a state of recession (RECESS). ${ }^{18}$ We also include dummy variables for the Napoleonic Wars (NAP: 1803-1815), the First World War (WWI: 1914-1918) and the Second World War (WWII: 1939-1945).

Amongst the dummy variables, only the Pax Britannica and Second World War terms are significant in the full specification given in Table 2 (column 5). Although the premium remains significant throughout, the inflation terms, the recession dummy, the gold standard dummy and the

\footnotetext{
${ }^{16}$ Alternatively, if we restrict the PAX dummy variable to only coincide with the reign of Queen Victoria, then the primary results do not change.

${ }^{17}$ The underlying wholesale price data are drawn from Global Financial Data, Inc. (http://www.globalfindata.com) based upon Gayer, Rostow and Schwartz (1953) for 1790-1850 and updated from various standard UK statistical sources for the post-1850 period. This does, however, restrict our estimation period to 1790 on as there are no data for earlier years.

${ }^{18}$ The recession dates for 1790-1850 are drawn from Gayer, Rostow and Schwartz (1953, p.348). The later recession dates are drawn from Burns and Mitchell (1946) and Dow (1998).
} 
WWI dummy all have standard errors larger than the estimated coefficients. ${ }^{19}$ The Napoleon dummy is also insignificant. The PAX dummy is significant at the $95 \%$ confidence level with the expected negative sign. This confirms the impression of the graphical display in Figure 3 and suggests that, at least in Britain's case, the classical gold standard was not the major factor in explaining the dramatic reduction in the variance of consol returns. If we also restimate the model over the full 1729-1959 sample without the inflation and recession variables (which are available only from 1790), we find that the PAX dummy remains significant at the $95 \%$ and the WWII dummy is still significant -- albeit only at the 90\% level (Table 2 (column (4)). The premium variable remains significant at the $99 \%$ level, the NAPOLEON dummy is significant at the $90 \%$ level while the inflation terms and RECESS and GOLD dummies are all insignificant.

Finally, we also re-ran the t-GARCH model over a more restricted 1790-1913 period to exclude the later upward drift in prices after the outbreak of the First World War. The results in Table 3 reaffirm the significance of the PAX dummy. The PREMIUM variable also continues to be significant at the $99 \%$ level while the inflation terms and the NAPOLEON, the RECESS and GOLD dummies are all insignificant.

As shown in Table 4, the low volatility Pax Britannica period has higher average consol returns than both the preceding period and the post-Pax Britannica period and only the much shorter Second World War period features higher nominal returns than those enjoyed between 1816 and $1913 .^{20}$ Meanwhile, the stability of the British series after Waterloo appears to not only be high relative to its own past and future but also relative to other national government securities. Table 5

\footnotetext{
${ }^{19}$ The same holds true if we expand our definition of the classical gold standard to cover the full 1870-1913 period. Meanwhile, the insignificance of the macroeconomic variables accords with their small explanatory power in prior analysis of financial data.

${ }^{20}$ Pax Britannica does not feature consistently lower inflation volatility or lower incidence of recession, however.
} 
reports the standard deviations of consol returns and French government 3\% rentes over the 1825 1949 period for which the French series is available. The French data, like the consols, are taken from the Global Financial database (http://www.globalfindata.com). Over the whole period for which rentes data are available, and also over the 1825-1913 period, the standard deviation of the French rentes is approximately double that of the British consols. Interestingly, the standard deviation of consol returns before Pax Britannica stands, like the rentes standard deviation, at almost exactly double the Pax Britannica level.

\section{Conclusions}

The consol data certainly indicate a period of greater financial stability during the era of Pax Britannica. The impact of Britain's leadership may also have been transmitted abroad. It is telling that Ferguson and Schularick (2004) find that even foreign debt issuers within the British Empire enjoyed a reduction in borrowing costs compared to countries outside the empire. More controversially, Kindleberger (1986) goes even further in suggesting that the whole world system was better off under Britain's leadership. In any event, we have evidence of a striking relationship between political stability and volatility of consols, the bellwether financial instrument of the day. Economic and political stability are unlikely to be divorced from financial market volatility in other periods as well.

This line of research is also important to our broader understanding of volatility. Much of the research on volatility has focused on specific events and specific relationships between economic conditions and volatility. While such links exist and are important, they fail to explain much of the underlying volatility in financial markets. Our results suggest that the underlying 
political and economic stability better explains an extended period of reduced volatility. In a similar vein, Voth (2002) finds that the increased volatility surrounding the interwar period was due to greater political instability. This points to the need for better measures of economic and political stability and supports their use in future research of volatility over time. In addition, measuring the underlying stability of industries and the changing probability of important technological and regulatory changes in those industries may help to better explain volatility in cross-section studies. 


\section{References}

Bagehot, W., 1873. Lombard Street: A Description of the Money Market. Henry S. King, London.

Bai, J., Peron, P., 1998. Estimating and testing linear models with multiple structural changes. Econometrica $66,47-78$.

Banerjee, A., Lumsdaine, R.L., Stock, J.H., 1992. Recursive and sequential tests of the unit root and trend break hypotheses: theory and international evidence. Journal of Business and Economic Statistics 10, 271-287.

Barro, R.J., 1987. Government spending, interest rates, prices, and budget deficits in the United Kingdom, 1701-1918. Journal of Monetary Economics 20, 221-247.

Barro, R.J., 1999. Notes on optimal debt management. Journal of Applied Economics 2, 281289.

Berry, T.D., Howe, K.M., 1994. Public information arrival. Journal of Finance 49, 1331-1346.

Bollerslev, T., 1987. A conditionally heteroskedastik time series model for speculative prices and rates of return. Review of Economics and Statistics 69, 542-547.

Bordo, M.D., Dueker, M.J., Wheelock, D.C., 2003. Aggregate price shocks and financial stability: the United Kingdom 1796-1999. Explorations in Economic History 40, 143169.

Brown, A.J., 1955. The Great Inflation, 1939-1951. Oxford University Press, London.

Brown, R.L., Easton, S.A., 1989. Weak-form efficiency in the nineteenth century: a study of daily prices in the London market for 3 per cent consols, 1821-1860. Economica 56, 6170. 
Burns, A.F., Mitchell, W.C., 1946. Measuring Business Cycles. National Bureau of Economic Research, New York.

Cutler, D.M., Poterba, J.M., Summers, L.H., 1989. What moves stock prices? Journal of Portfolio Management 15, 4-12.

Dow, C., 1998. Major Recessions: Britain and the World, 1920-1995. Oxford University Press, Oxford.

Ederington, L.H., Lee, J.H., 1993. How markets process information: news releases and volatility. Journal of Finance 48, 1161-1191.

Elmendorf, D.W., Hirschfeld, M.L., Weil, D.N., 1996. The effect of news on bond prices: evidence from the United Kingdom, 1900-1920. Review of Economics and Statistics 78, 341-344.

Fair, R.C., 2002. Events that shook the market. Journal of Business 75, 713-731.

Fair, R.C., 2003. Shock effects on stocks, bonds, and exchange rates. Journal of International Money and Finance 22, 307-341.

Farwell, B., 1972. Queen Victoria's Little Wars. Harper \& Row, New York.

Ferguson, N., 2003. Political risk and the international bond market between the 1848 revolution and the outbreak of the First World War. Unpublished working paper, Oxford University.

Ferguson, N., Schularick, M., 2004. The empire effect: the determinants of country risk in the first age of globalization, 1880-1913. Unpublished working paper, New York University.

Fleming, M.J., Remolona, E.M., 1999. Price formation and liquidity in the U.S. Treasury market: the response to public information. Journal of Finance 54, 1901-1915. 
Gayer, A.D., Rostow, W.W., Schwartz, A.J., 1953. The Growth and Fluctuation of the British Economy, 1790-1850. Clarendon Press, Oxford.

Giffen, R., 1899. Consols in a great war. Economic Journal 9, 353-364.

Hargreaves, E.L., 1930. The National Debt. Edward Arnold, London.

Harley, C.K., 1976. Goschen's conversion of the national debt and the yield on consols.

Economic History Review 29, 101-106.

Harrod, R., 1958. Policy Against Inflation. Macmillan, London.

Jones, C.M., Lamont, O., Lumsdaine, R.L., 1998. Macroeconomic news and bond market volatility. Journal of Financial Economics 47, 315-337.

Kindleberger, C.P., 1986. The World in Depression, 1929-1939, revised and enlarged edition. University of California Press, Berkeley, California.

Klovland, J.T., 1994. Pitfalls in the estimation of the yield on British consols, 1850-1914. Journal of Economic History 54, 164-187.

Koehn, N.F., 1994. The Power of Commerce: Economy and Governance in the First British Empire. Cornell University Press, London.

Kynaston, D., 1995. The Bank of England and the government. In: Roberts, R., Kynaston, D. (Eds.), The Bank of England: Money, Power and Influence 1694-1994. Clarendon Press, Oxford, pp. 19-55.

Miller, A.C., 1890. The conversion of the English debt. Quarterly Journal of Economics 4, 437448.

Mitchell, H., Brown, R., Easton, S., 1994. Old volatility-ARCH effects in $19^{\text {th }}$ century consol data. Applied Financial Economics 12, 301-307. 
Mitchell M.L., Mulherin, J.H., 1994. The impact of public information on the stock market. Journal of Finance 49, 923-950.

Neal, L., 1990. The Rise of Financial Capitalism: International Capital Markets in the Age of Reason. Cambridge University Press, Cambridge.

Neal, L., 1998. The financial crisis of 1825 and the restructuring of the British financial system. Federal Reserve Bank of St. Louis Review 80, 53-76.

Neal, L., 2000. How it all began: the monetary and financial architecture of Europe during the first global capital markets, 1648-1815. Financial History Review 7, 117-140.

Nelson, D.B., 1991. Conditional heteroskedasticity in asset returns: a new approach. Econometrica 59, 347-370.

Niederhoffer, V., 1971. The analysis of world events and stock prices. Journal of Business 44, 193-219.

Penman, S.H., 1987. The distribution of earnings news over time and seasonalities in aggregate stock returns. Journal of Financial Economics 18, 199-228.

Roll, R., 1988. R². Journal of Finance 43, 541-566.

Schwert, G.W., 1989a. Why does stock market volatility change over time? Journal of Finance 44, 1115-1153.

Schwert, G.W., 1989b. Business cycles, financial crisis and stock volatility. Carnegie-Rochester Conference Series on Public Policy 31, 83-125.

Schwert, G.W., 2002. Stock volatility in the new millennium: how wacky is Nasdaq? Journal of Monetary Economics 49, 3-26. 
Sylla, R., Wilson, J.W., Wright, R.E., 2004. Integration of Trans-Atlantic capital markets, 17901845. Unpublished working paper, New York University.

Talmor, E., Haugen, R.A., Torous, W.N., 1991. The effect of volatility changes on the level of stock prices and subsequent expected returns. Journal of Finance 46, 985-1007.

Voth, H.-J., 2002. Why was stock market volatility so high during the Great Depression? evidence from 10 countries during the interwar period. Working Paper 02-09, Department of Economics, Massachusetts Institute of Technology. 
Table 1

Biggest One Month Changes in 3\% Consol Prices, 1729-1959

Panel A presents the 10 largest month to month changes in consol prices and the events most likely associated with those changes. Panel B provides the equivalent information for the ten largest monthly declines in consol prices. The consol data are taken from Global Financial Data, Inc. (http://www.globalfindata.com).

Date $\quad$ Change $\quad$ Major Events

Panel A: Positive Shifts

1. October 1801

2. August $1762 \quad 13.95 \%$

3. June $1797 \quad 13.58 \%$

4. April $1761 \quad 13.37 \%$

5. April $1748 \quad 12.23 \%$

6. July $1932 \quad 11.47 \%$

7. January $1814 \quad 11.16 \%$

8. October $1798 \quad 11.14 \%$

9. June $1799 \quad 10.49 \%$

10. February $1762 \quad 9.90 \%$

Panel B: Negative Shifts

1. November $1792 \quad-12.86 \%$

2. March $1778 \quad-12.84 \%$

3. March $1803 \quad-12.65 \%$

4. March $1814 \quad-10.83 \%$

5. January $1915 \quad-9.82 \%$

6. February $1937 \quad-9.37 \%$

7. September $1799 \quad-9.01 \%$

8. July $1803 \quad-8.95 \%$

9. March $1815 \quad-8.81 \%$

10. September $1931 \quad-8.69 \%$
French evacuation of Egypt in September 1801

Havana captured from Spain on August 12, 1762

Easing of credit market conditions after the financial crisis of February 1797

French expelled from India; Pondicherry surrendered on January 15, 1761

War with France over; Treaty of Aix-la-Chapelle set for October 1748

Bank rate cut to 2\% in June 1932 under the War Loan conversion

Napoleon on the ropes; Marshall Murat signs peace treaty with the Allies on January 11, 1814

Irish rebellion crushed in September 1798; French expeditionary force defeated

Britain joins the Second Coalition against France on June 22, 1799; income tax collections begin

Capture of French Caribbean territories; Martinique falls on February 13 and St. Lucia on February 25, 1762

French revolutionary war underway against Austria and Prussia; revolutionary victory at Jemappes on November 6, 1792

France joins the American fight against British rule; American treaties with France and the Netherlands signed in February 1778

War with Napoleon imminent; fighting begins in May 1803

French victories in early March but Napoleon defeated and Paris surrendered on March 31, 1814; fighting continues with the United States

First month of trading after the outbreak of the First World War; market closed from August-December 1914

Nationalist offensive in Spain with Malaga captured on February 6, 1937; Govt. proposes $£ 400$ million loan for re-armament expenditures Russian army defeated at Zurich on September 26, 1799; withdraws from Second Coalition against France

Beginning of Napoleonic wars; war declared on May 16, 1803

Napoleon returns from Elba; Paris reclaimed on March 20, 1815

Britain exits the gold standard on September 21, 1931 
Table 2

GARCH(1, 1) Models of Consol Return Volatility, 1729-1959

The GARCH $(1,1)$ model for consol returns can be written as:

$$
\begin{aligned}
& \operatorname{RETURN}_{t}=\delta \operatorname{RETURN}_{t-1}+\varepsilon_{t} \\
& h_{t}=\omega_{0}+\alpha \varepsilon_{t-1}^{2}+\beta h_{t-1}+\gamma \operatorname{PREMIUM}_{t}+a_{1} \mathrm{INF}_{\mathrm{t}-1}+a_{2} \mathrm{INF}_{\mathrm{t}-2}+a_{3} \mathrm{INF}_{\mathrm{t}-3}+a_{4} \mathrm{RECESS}_{\mathrm{t}}+ \\
& a_{5} \mathrm{NAP}_{\mathrm{t}}+a_{6} \mathrm{PAX}_{\mathrm{t}}+a_{7} \mathrm{GOLD}_{\mathrm{t}}+a_{8} \mathrm{WWI}_{\mathrm{t}}+a_{9} \mathrm{WWII}_{\mathrm{t}}
\end{aligned}
$$

$R_{t}$ is the rate of return for British consols in month $t$ where return is defined as the natural log of the consol price in month $t$ minus the natural log of the consol price in month $t-1 . h_{t}$ is the conditional variance of the consol return for month $t$. The $\operatorname{GARCH}(1,1)$ models are estimated using maximum likelihood with a t-distribution. We estimated the degrees of freedom to be approximately 5 - 6 for all the models. The PREMIUM variable is defined as the percentage difference between the natural log of the bond price and the natural log of 100 . The inflation variable (INF) is defined as the natural log of monthly wholesale prices in month $t$ minus the natural log of monthly wholesale prices in month $\mathrm{t}-1$. The wholesale price series is based upon Gayer, Rostow and Schwartz (1953) for 1790-1850 and updated from various standard UK statistical sources for the post-1850 period. The recession variable is a dummy variable that is equal to one during an economic downturn and zero otherwise. The recession dates for 17901850 are taken from Gayer, Rostow and Schwartz (1953, p.348). The later recession dates are drawn from Burns and Mitchell (1946) and Dow (1998). The war dummies are zero-one indicator variables representing the Napoleonic Wars (NAP: May 1803- May 1815), the First World War (WWI: August 1914 - November 1918) and the Second World War (WWII: September 1939 - August 1945). The PAX variable takes a value of one for the period 18161913 and zero otherwise. GOLD is a dummy variable that takes the value of one during the classical gold standard period (1880-1913). The sample size is 2762.

\begin{tabular}{cccccc}
\hline & & & (sample period) & & \\
Variable & Sept. 1729 & Sept. 1729 & Mar. 1790 & Sept. 1729 & Mar. 1790 \\
& to Dec. & to Dec. & to & to Dec. & to \\
1959 & 1959 & Dec.1959 & 1959 & Dec.1959 \\
\hline
\end{tabular}

$\begin{array}{cccccc}\delta & 0.029 & 0.029 & 0.035 & 0.034 & 0.039 \\ (\mathrm{AR}(1)-\text { Mean) } & (0.018) & (0.019) & (0.022) & (0.018)^{*} & (0.023)^{*} \\ \omega & & & & & \\ \text { (constant in } h_{t} \text { equation) } & (0.014)^{* * *} & (0.018)^{* * *} & (0.014)^{* *} & (0.037)^{* * *} & (0.073)^{* * *} \\ \alpha \text { (ARCH) } & 0.132 & 0.137 & 0.1 & 0.116 & 0.089 \\ & (0.017)^{* * *} & (0.019)^{* * *} & (0.017)^{* * *} & (0.017)^{* * *} & (0.018)^{* * *}\end{array}$




\begin{tabular}{|c|c|c|c|c|c|}
\hline$\beta(\mathrm{GARCH})$ & $\begin{array}{c}0.872 \\
(0.013)^{* * *}\end{array}$ & $\begin{array}{c}0.844 \\
(0.017)^{* * *}\end{array}$ & $\begin{array}{c}0.887 \\
(0.016)^{* * *}\end{array}$ & $\begin{array}{c}0.862 \\
(0.016)^{* * *}\end{array}$ & $\begin{array}{c}0.883 \\
(0.022)^{* * *}\end{array}$ \\
\hline$\gamma($ PREMIUM $)$ & & $\begin{array}{c}-0.004 \\
(0.001)^{* * *}\end{array}$ & $\begin{array}{c}-0.001 \\
(0.0007)^{* *}\end{array}$ & $\begin{array}{c}-0.097 \\
(0.022)^{* * *}\end{array}$ & $\begin{array}{c}-0.071 \\
(0.023)^{* * *}\end{array}$ \\
\hline$\alpha_{1}\left(\mathrm{INF}_{\mathrm{t}-1}\right)$ & & & $\begin{array}{l}-0.031 \\
(0.039)\end{array}$ & & $\begin{array}{l}-0.033 \\
(0.039)\end{array}$ \\
\hline$\alpha_{2}\left(\mathrm{INF}_{\mathrm{t}-2}\right)$ & & & $\begin{array}{c}0.038 \\
(0.052)\end{array}$ & & $\begin{array}{c}0.004 \\
(0.052)\end{array}$ \\
\hline$\alpha_{3}\left(\mathrm{INF}_{\mathrm{t}-3}\right)$ & & & $\begin{array}{c}0.002 \\
(0.036)\end{array}$ & & $\begin{array}{c}0.013 \\
(0.037)\end{array}$ \\
\hline$\alpha_{4}\left(\mathrm{RECESS}_{\mathrm{t}}\right)$ & & & $\begin{array}{l}0.0003 \\
(0.019)\end{array}$ & & $\begin{array}{l}-0.001 \\
(0.019)\end{array}$ \\
\hline$\alpha_{5}\left(\mathrm{NAP}_{\mathrm{t}}\right)$ & & & & $\begin{array}{c}0.214 \\
(0.121)^{*}\end{array}$ & $\begin{array}{c}0.105 \\
(0.102)\end{array}$ \\
\hline$\alpha_{6}\left(\mathrm{PAX}_{\mathrm{t}}\right)$ & & & & $\begin{array}{c}-0.07 \\
(0.031)^{* *}\end{array}$ & $\begin{array}{c}-0.138 \\
(0.061)^{* *}\end{array}$ \\
\hline$\alpha_{7}\left(\mathrm{GOLD}_{\mathrm{t}}\right)$ & & & & $\begin{array}{c}-0.01 \\
(0.019)\end{array}$ & $\begin{array}{c}-0.01 \\
(0.019)\end{array}$ \\
\hline$\alpha_{8}(\mathrm{WWI})$ & & & & $\begin{array}{c}0.119 \\
(0.193)\end{array}$ & $\begin{array}{c}0.022 \\
(0.164)\end{array}$ \\
\hline$\alpha_{9}(\mathrm{WWII})$ & & & & $\begin{array}{c}-0.067 \\
(0.037)^{*}\end{array}$ & $\begin{array}{l}-0.142 \\
(0.071)^{* *}\end{array}$ \\
\hline Function value & -5304.422 & -5297.449 & -3801.324 & -5282.666 & -3792.709 \\
\hline
\end{tabular}

*** denotes significance at the $99 \%$ confidence level, ** denotes significance at the $95 \%$ level, and $*$ denotes significance at the $90 \%$ level. 
Table 3

GARCH(1, 1) Models of Consol Return Volatility, 1790-1913

The model is the same as described in Table 2 with the only difference being the estimation period. The sample size is 1486 .

\begin{tabular}{|c|c|c|c|c|}
\hline \multirow[b]{2}{*}{ Variable } & \multicolumn{4}{|c|}{ (sample period) } \\
\hline & $\begin{array}{l}\text { Mar. } 1790 \text { to } \\
\text { Dec. } 1913\end{array}$ & $\begin{array}{l}\text { Mar. } 1790 \text { to } \\
\text { Dec.1913 }\end{array}$ & $\begin{array}{l}\text { Mar. } 1790 \text { to } \\
\text { Dec. } 1913\end{array}$ & $\begin{array}{l}\text { Mar. } 1790 \text { to } \\
\text { Dec. } 1913\end{array}$ \\
\hline \multirow{2}{*}{$\begin{array}{c}\delta \\
\operatorname{AR}(1)\end{array}$} & 0.008 & 0.013 & 0.012 & 0.012 \\
\hline & $(0.028)$ & $(0.029)$ & $(0.025)$ & $(0.028)$ \\
\hline$\omega$ & 0.018 & 0.024 & 0.02 & 0.237 \\
\hline (constant in $h_{t}$ equation) & $(0.008)^{* *}$ & $(0.008)^{* * *}$ & $(0.010)^{* *}$ & $(0.118)^{* * *}$ \\
\hline \multirow[t]{2}{*}{$\alpha(\mathrm{ARCH})$} & 0.065 & 0.067 & 0.067 & 0.071 \\
\hline & $(0.018)^{* * *}$ & $(0.017)^{* * *}$ & $(0.016)^{* * *}$ & $(0.014)^{* * *}$ \\
\hline \multirow[t]{2}{*}{$\beta(\mathrm{GARCH})$} & 0.927 & 0.922 & 0.923 & 0.905 \\
\hline & $(0.018)^{* * *}$ & $(0.017)^{* * *}$ & $(0.016)^{* * *}$ & $(0.014)^{* * *}$ \\
\hline \multirow[t]{2}{*}{$\gamma(\mathrm{PREMIUM})$} & & -0.062 & -0.066 & -0.079 \\
\hline & & $(0.019)^{* * *}$ & $(0.019)^{* * *}$ & $(0.023)^{* * *}$ \\
\hline \multirow{2}{*}{$\alpha_{1}\left(\mathrm{INF}_{\mathrm{t}-1}\right)$} & & & -0.032 & -0.034 \\
\hline & & & $(0.027)$ & $(0.025)$ \\
\hline \multirow[t]{2}{*}{$\alpha_{2}\left(\mathrm{INF}_{\mathrm{t}-2}\right)$} & & & 0.014 & 0.002 \\
\hline & & & $(0.049)$ & $(0.043)$ \\
\hline \multirow[t]{2}{*}{$\alpha_{3}\left(\mathrm{INF}_{\mathrm{t}-3}\right)$} & & & 0.013 & 0.019 \\
\hline & & & $(0.035)$ & $(0.032)$ \\
\hline \multirow[t]{2}{*}{$\alpha_{4}\left(\operatorname{RECESS}_{\mathrm{t}}\right)$} & & & 0.006 & -0.0003 \\
\hline & & & $(0.013)$ & $(0.013)$ \\
\hline \multirow[t]{2}{*}{$\alpha_{5}\left(\mathrm{NAP}_{\mathrm{t}}\right)$} & & & & 0.007 \\
\hline & & & & $(0.089)$ \\
\hline \multirow[t]{2}{*}{$\alpha_{6}\left(\mathrm{PAX}_{\mathrm{t}}\right)$} & & & & -0.198 \\
\hline & & & & $(0.022)^{* * * *}$ \\
\hline$\alpha_{7}\left(\mathrm{GOLD}_{\mathrm{t}}\right)$ & & & & -0.005 \\
\hline
\end{tabular}


$* * *$ denotes significance at the $99 \%$ confidence level, $* *$ denotes significance at the $95 \%$ level, and $*$ denotes significance at the $90 \%$ level. 
Table 4

Descriptive Statistics for Consol Returns, Inflation, and Recessions by Period Monthly Consol Returns are defined as the natural log of the consol price in month $t$ minus the natural log of the consol price in month $\mathrm{t}-1$. Inflation is the monthly change in the natural log of the wholesale price series. The recession variable is a zero-one indicator variable that is equal to one when the economy is in a recession. The sources for the data and further data descriptions are provided in Table 1 and Table 2.

\begin{tabular}{|c|c|c|c|}
\hline Sample Period & $\begin{array}{c}\text { Monthly } \\
\text { Consol Returns }\end{array}$ & $\begin{array}{l}\text { Monthly } \\
\text { Inflation }\end{array}$ & $\begin{array}{l}\text { Monthly } \\
\text { Recession }\end{array}$ \\
\hline \multicolumn{4}{|c|}{ Full Sample (1729 to 1959$)$} \\
\hline Mean & $-0.022 \%$ & $0.063 \%$ & $35.427 \%$ \\
\hline Standard Deviation & $2.146 \%$ & $2.104 \%$ & $47.841 \%$ \\
\hline \multicolumn{4}{|c|}{ Pax Britannica (1816 to 1913 ) } \\
\hline Mean & $0.014 \%$ & $-0.034 \%$ & $40.646 \%$ \\
\hline Standard Deviation & $1.390 \%$ & $2.171 \%$ & $49.138 \%$ \\
\hline \multicolumn{4}{|c|}{ Pre-Pax Britannica (1729 to 1815 ) } \\
\hline Mean & $-0.039 \%$ & $0.086 \%$ & $38.720 \%$ \\
\hline Standard Deviation & $2.733 \%$ & $2.482 \%$ & $48.787 \%$ \\
\hline \multicolumn{4}{|c|}{ Post-Pax Britannica (1913 to 1959 ) } \\
\hline Mean & $-0.065 \%$ & $0.255 \%$ & $22.464 \%$ \\
\hline Standard Deviation & $2.220 \%$ & $1.674 \%$ & $41.772 \%$ \\
\hline \multicolumn{4}{|c|}{ Gold Standard (1880 to WWI) } \\
\hline Mean & $-0.075 \%$ & $0.012 \%$ & $39.706 \%$ \\
\hline Standard Deviation & $0.897 \%$ & $1.249 \%$ & $48.989 \%$ \\
\hline \multicolumn{4}{|l|}{ World War I } \\
\hline Mean & $-0.404 \%$ & $1.659 \%$ & $7.692 \%$ \\
\hline Standard Deviation & $2.489 \%$ & $2.005 \%$ & $26.907 \%$ \\
\hline \multicolumn{4}{|l|}{ World War II } \\
\hline Mean & $0.398 \%$ & $0.769 \%$ & $0.000 \%$ \\
\hline Standard Deviation & $1.366 \%$ & $1.451 \%$ & $0.000 \%$ \\
\hline
\end{tabular}


Table 5:

Comparison of Consol and French Rente Return Standard Deviations

The standard deviations of consol returns and French government 3\% rentes over the 1825-1949 period for which the French series is available. The French data, like the consols, are taken from the Global Financial database (http://www.globalfindata.com). The standard deviation of the consol returns for the PAX period is only for the period of overlap (1825-WWI) and not for the entire Pax Britannica period (1816-1913). In addition, the Post-Pax Britannica period ends with the Rente sample in 1949 instead of 1959.

\begin{tabular}{lll}
\hline & $\begin{array}{l}\text { Standard Deviation of } \\
\text { Sample Period }\end{array}$ & $\begin{array}{l}\text { Standard Deviation of } \\
\text { Monthly Rente Returns }\end{array}$ \\
Monthly Consol Returns
\end{tabular}

Consols and Rentes Compared

Full Rente Sample (1825-1949)

$2.89 \%$

Pax Britannica (1825-WWI)

$2.61 \%$

$1.21 \%$

Gold (1880-WWI)

$1.49 \%$

$0.90 \%$

Post Pax Britannica (1914-1949)

$3.49 \%$

$2.28 \%$ 


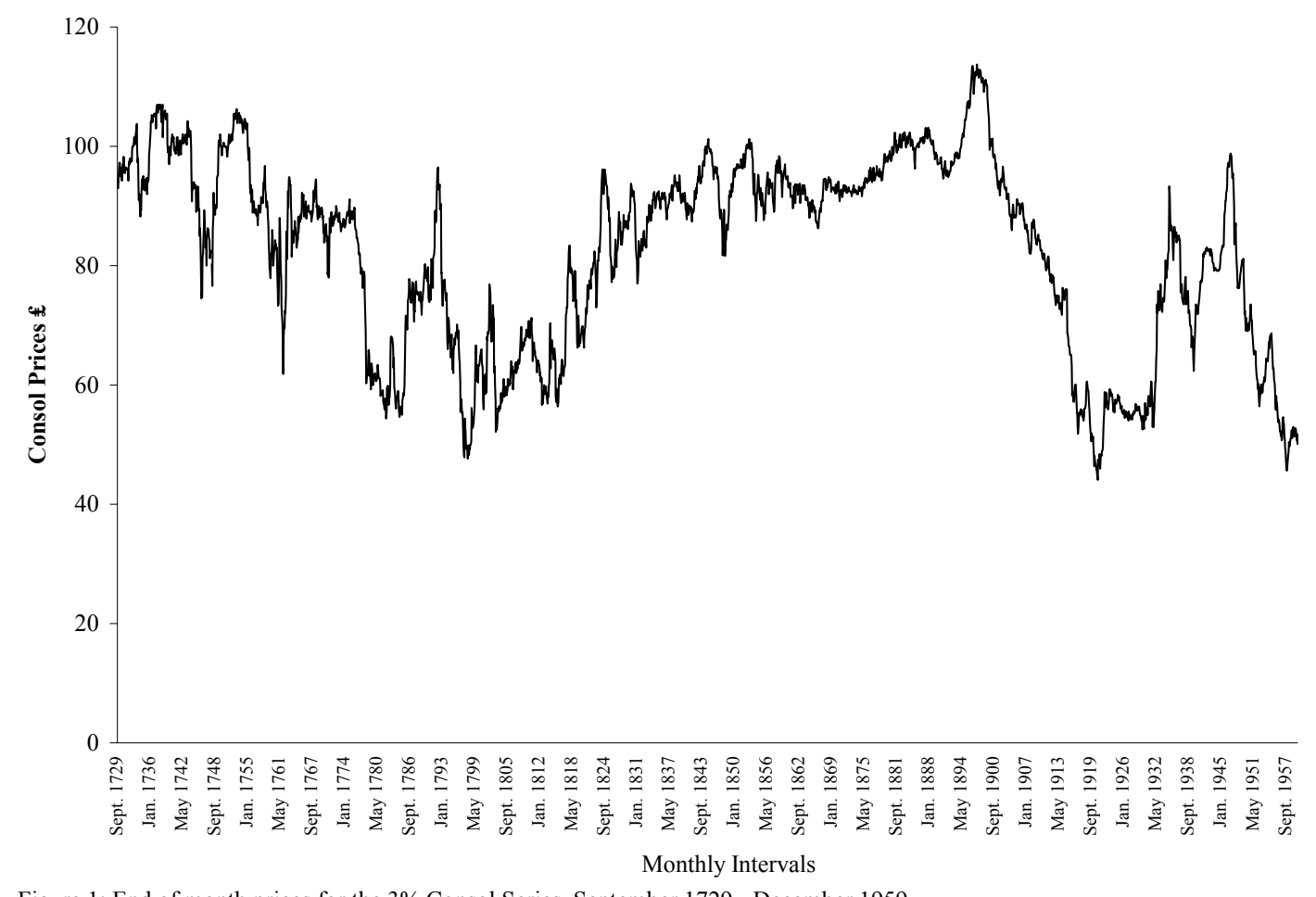

Figure 1: End of month prices for the 3\% Consol Series, September 1729 - December 1959 


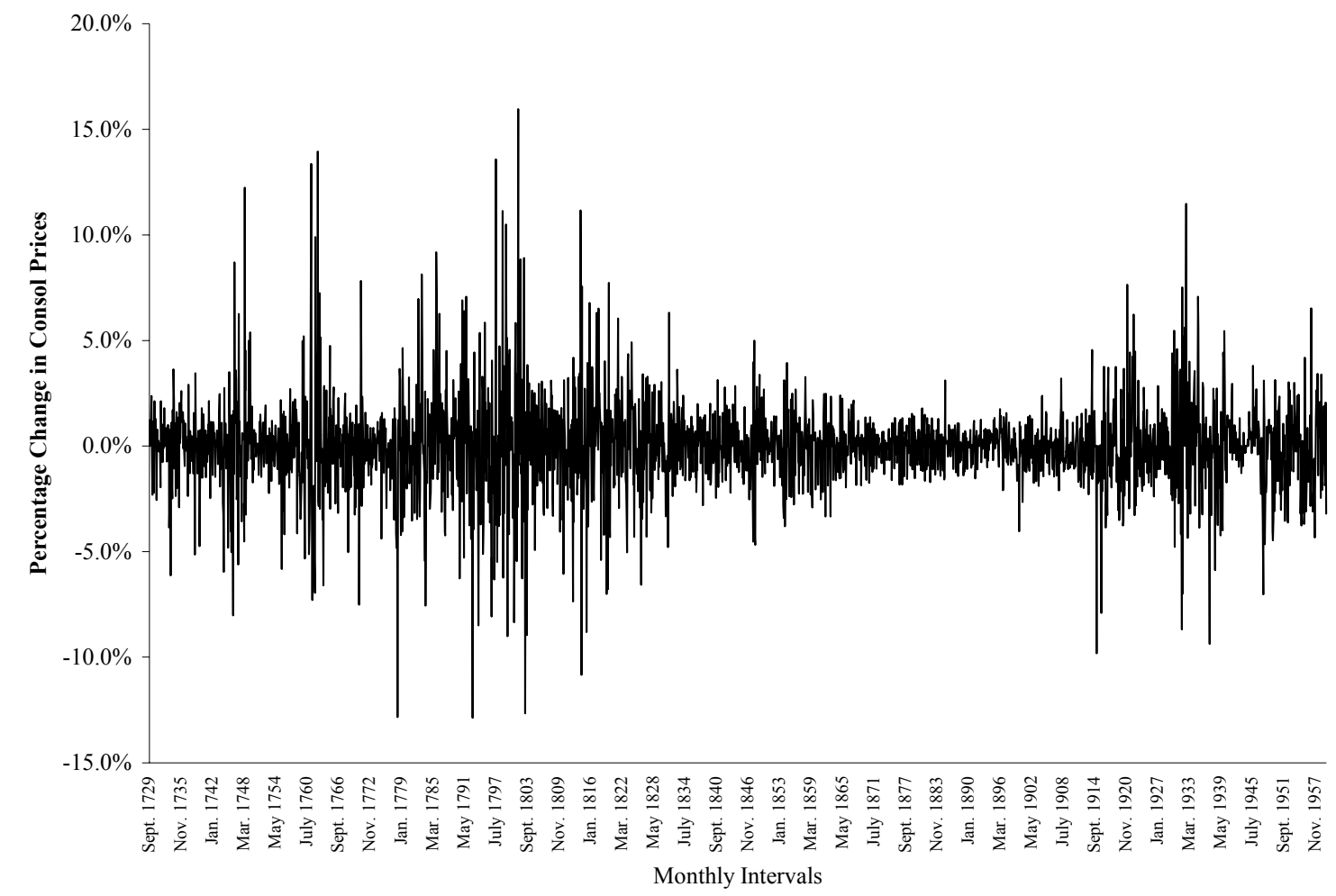

Figure 2: Monthly Percentage Changes in Consol Prices, September 1729 - December 1959 


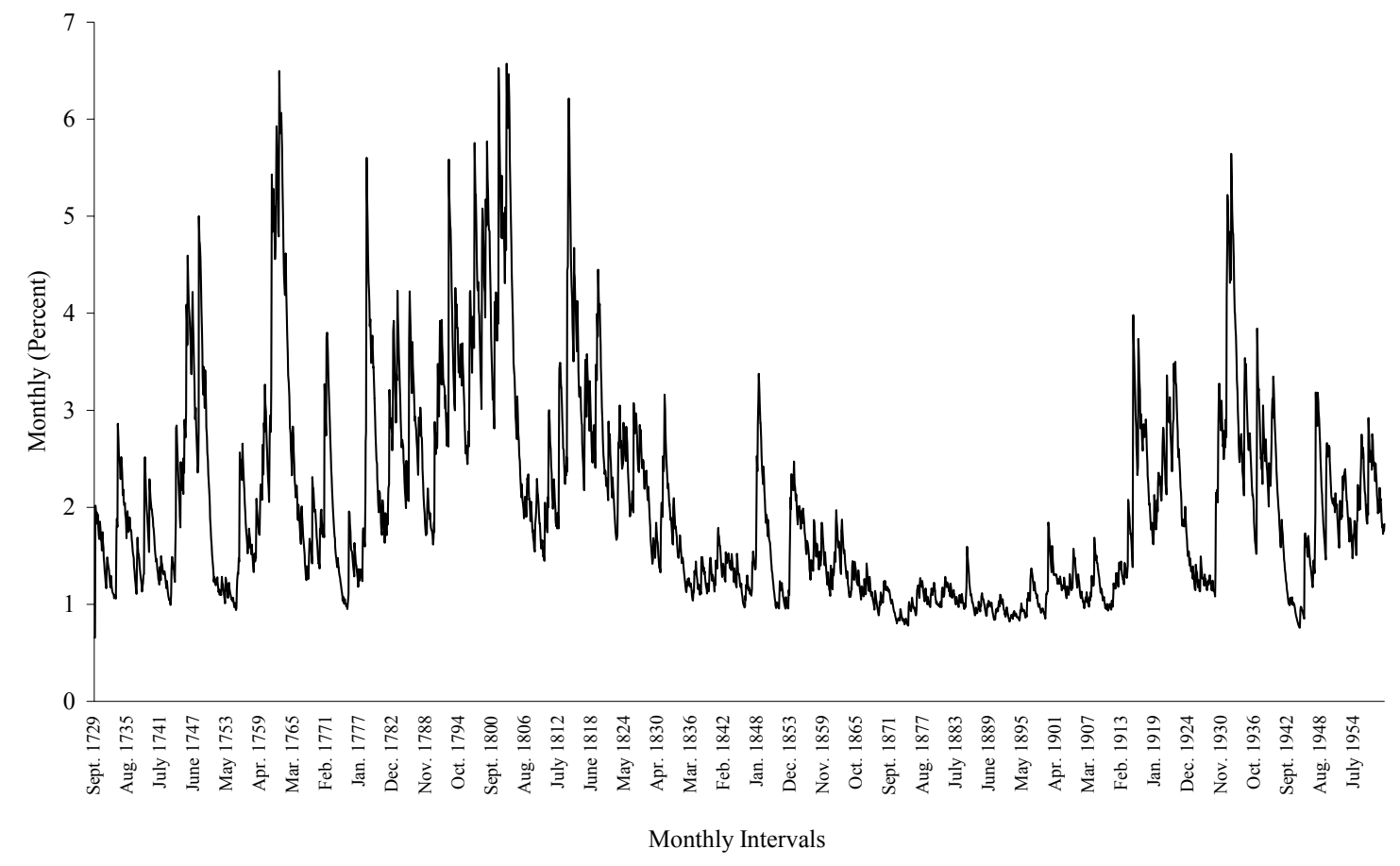

Figure 3: Conditional Standard Deviation of Consol Returns, September 1729 - December 1959 